\title{
Toward Safer, More Sustainable California Communities
}

Ken Topping, FAICP, is a lecturer at Cal Poly's CRP Department. He

is a former planning director for the City of Los Angeles and for San Bernardino County, and from 2000-2004 he was visiting professor at the Disaster Prevention Research Institute, Kobe University, Japan.

${ }^{1}$ CRP Project Team: Ken Topping (project director); William

Siembieda and Michael Boswell (co-directors); graduate assistants Geof Chiapella, James David,

Matt Maxwell, and Lily Schinsing

Cal Poly Advisory Reviewers: Rakesh Goel and Robb Moss (College of Civil and Environmental Engineering), Chris Dicus (Forestry and Natural Resources Management Department), and James Sena (Orfalea College of Business).
The CRP Department has been a leader in research and education in the areas of urban disaster risk reduction, prevention, mitigation, and post-recovery. The international symposium held in 2005 and its proceedings published by FOCUS are examples of that. Lecturer Ken Topping writes about the revision of the California State Multi-Hazard Mitigation Plan, a major applied research project undertaken by the CRP Department.

A major applied research project undertaken by the City and Regional Planning Department during 2006-2007 is revision of the California State Multi-Hazard Mitigation Plan. The work is being financed through a $\$ 762,894$ contract between the Cal Poly Corporation and the California Governor's Office of Emergency Services (OES).

The project is being carried out by CRP faculty having special expertise in hazard mitigation and graduate assistants, and is also supported by advisees from other departments and outside consultants. ${ }^{1}$ Together they have closely examined and assessed FEMA-approved Local Hazard Mitigation Plans (LHMPs) of 424 local governments, including 164 prepared by cities, 21 prepared by counties, and 239 prepared by special districts in California.

Approved by FEMA in November 2004, the State Multi-Hazard Mitigation Plan (SHMP) is a statewide plan under the Disaster Mitigation Act of 2000 to identify and profile, assess vulnerabilities and risks, estimate potential losses, and promote strategies and actions for mitigation of a variety of natural and human-cased hazards such as floods, earthquakes, and wildfires.

An overall goal of this plan revision is to help institutionalize mitigation planning and action across the boundaries of state agencies, local governments, business and industry, and community groups. OES recognizes the need to energize effective mitigation actions at all levels. The effort to link the SHMP with over the LHMPs of over 400 local governments addresses the need to tie hazard mitigation to routine development planning and infrastructure management.

Cal Poly is revising the 2004 SHMP so it can be approved by FEMA as an Enhanced Plan. According to the FEMA guidance criteria an Enhanced Plan ..."documents the State's demonstrable and sustained commitment to the objectives of hazard mitigation... recognizes the State as a proactive leader in implementing a comprehensive statewide program....and acknowledges the extra effort a State has made to reduce losses, protect its resources, and create safer communities."

California's financial stakes for receiving FEMA approval of the 2007 SHMP as an Enhanced Plan are high. Enhanced Plan status would qualify the state for Hazard Mitigation Grant Program (HMGP) funding of up to $20 \%$ of a federally declared disaster authorization following future disasters, as opposed to receiving only $71 / 2-15 \%$ with the current Standard Plan, depending upon the size of the disaster-the larger the disaster, the lesser the amount. This would make a major difference in the event of a catastrophic disaster

In the revised 2007 SHMP Cal Poly is addressing a variety of new conditions, laws, and programs which have been encountered since the current plan was published and which can potentially affect 
the State of California, including: climate change, tsunami mitigation and preparedness, and San Francisco Bay Delta regional levee failure potential. Cal Poly and OES are using GIS modeling to jointly prepare a systematic statewide risk analyses for major hazards (earthquakes, wildfires, and floods) to identify the distribution of hazards and their interrelationships within a multi-hazard policy framework.

The project schedule includes release of an initial administrative draft 2007 SHMP revision for comment by state agencies by the end of March, 2007, circulation of public comment draft from July through September 2007, and publication of a final FEMA-approved manuscript by October.

\section{Interdisciplinary Sustainable Environments Curriculum Advancement}

The State Mitigation Plan Revision Project is tied with a series of initiatives in recent years to address disaster management and sustainability in conjunction with the College of Architecture and Environmental Design and other colleges. CRP has supported and promoted courses and specialties in environmental design and disaster management at both the graduate and undergraduate levels.

In addition to a Masters of City and Regional Planning in Environmental Planning, undergraduate City and Regional Planning majors can earn a minor in Environmental Management. Catalog courses supporting sustainability include Environmental Design 406, 408, and 410, a series of upper division and graduate interdisciplinary courses offered with the College of Architecture and Environmental Design which emphasize concepts and principles of sustainability to be used in all aspects of environmental design. More specific to the connection between disaster management, sustainability, and city and regional planning are two new courses recently added to the catalog.

UNIV 339, Disaster Resistant Sustainable Communities: offered as a lower division Universitywide elective. It is designed to provide an understanding of the tools, techniques, and processes for reducing risk and vulnerability to natural, technological, and human-caused hazards. It emphasizes basic sciences of hazards (earthquakes, landslides, floods, hurricanes, and wildfires) with the application of technical tools and community solutions to hazard mitigation.

CRP 458, Community Safety Planning and Design: an interdepartmental course for future design professionals, natural resource managers, and community administrators, offered as an upper division and graduate elective. It provides an understanding of specific community planning, design and development tools, techniques, and processes available for reducing risk and vulnerability to natural, technological, and human-caused hazards, and for securing suitable post-disaster redevelopment.

\section{Global Outreach}

Much of the inspiration for these new initiatives are related to the International Symposium on Urban Disaster Reduction and Regeneration (November, 2005) sponsored by Cal Poly's College of Architecture and Environmental Design, which the CRP Department was instrumental in organizing. ${ }^{2}$ The symposium featured presentations by prominent disaster management experts from Costa Rica, Japan, the Philippines, Taiwan, and Venezuela as well as the US. The symposium identified a variety or challenges and opportunities in pre-career and mid-career curriculum development in environmental management, sustainable development, and disaster management. Proceedings of this event were published as a special issue of FOCUS in 2006, and can also be found at the following website: http://
${ }^{2}$ See Christina Batteate's article "Cal Poly's Symposium on Disaster Risk Reduction and Regeneration Planning: An Overview", in FOCUS III, 2006. 